\title{
empresários alemães no sul do brasil: a trajetória da kolonisations-verein von 1849 in hamburg (1846-1855)
}

\section{german businessman in the south of brazil: the history of the kolonisations-verein von 1849 in hamburg (1846-1855)}

\author{
Luiz Mateus da Silva Ferreira ${ }^{\star \star}$ \\ Departamento de Economia, Universidade Federal de Ouro Preto, Mariana, Minas Gerais, Brasil
}

RESUMO

Este artigo analisa a trajetória da Kolonisations- Verein von 1849 in Hamburg no período de 1846 a 1855.A análise demonstra que foram as expectativas em relação ao comércio entre Brasil e Hamburgo e ao crescente negócio do transporte de emigrantes que motivaram um grupo composto por grandes negociantes, armadores, banqueiros e políticos de Hamburgo a se reunir em 1846 para organizar e dirigir a emigração alemã para o sul do Brasil. Para tanto, foi constituída a Kolonisations-Verein von 1849, uma das maiores firmas estrangeiras de colonização a atuar no Brasil no século XIX. Em 1851, essa empresa estabeleceu, na província de Santa Catarina, a colônia Dona Francisca, um dos mais importantes núcleos de colonização alemã do país. As evidências apresentadas neste estudo demonstram que, apesar de ser uma empresa privada, com interesses comerciais específicos, a Kolonisations-Verein von 1849 naufragaria poucos anos depois da sua fundação não fosse o auxílio financeiro do governo brasileiro.

Palavras-chave: Kolonisations-Verein von 1849 in Hamburg. Colonização alemã. Santa Catarina. Brasil. Colônia Dona Francisca. Século XIX.

\begin{abstract}
This article analyzes the history of the Kolonisations-Verein von 1849 in Hamburg in the period from 1846 to 1855 . The analysis has shown that it was the expectations of trade between Brazil and Hamburg and the growing business of emigrant transportation that motivated a group of large merchants, shipowners, bankers and politicians from Hamburg to meet in 1846 in order to organize and conduct German emigration to south of Brazil. For that purpose was created the Kolonisations-Verein von 1849, one of the largest foreign colonization firms operating in Brazil during nineteenth century. In 1851, that company established, in the province of Santa Catarina, the Dona Francisca colony, one of the most important centers of German colonization in Brazil. The presented evidences in this investigation has shown that, despite being a private company, with specific business interests, the Kolonisations-Verein von 1849 , would go bankrupt a few years after its foundation if it was notfor the financial support of the Brazilian government.
\end{abstract}

Keywords: Kolonisations-Verein von 1849 in Hamburg. German colonization. Santa Catarina. Brazil. Dona Francisca colony. Nineteenth century.

* Submissão: 14/10/2019; aprovação: 16/05/2020.

$\star \star$ Professor do Departamento de Economia da Universidade Federal de Ouro Preto (UFOP). Instituto de Ciências Sociais Aplicadas (ICSA).E-mail:luiz.ferreira@ufop. edu.br. ORCID: <https://orcid.org/0000-0002-8177-5443>. 


\section{Introdução}

A partir de meados da década de 1840, a migração alemã intercontinental cresceu rápida e expressivamente. Entre 1844 e 1847, o número de alemães que migraram da Europa para os países do Novo Mundo subiu de mais ou menos 16,8 mil pessoas em 1843 para mais de 45,6 mil em 1844; no ano seguinte esse número foi superior a 73,2 mil, alcançando quase 93,8 mil em 1846, e mais de 108,4 mil emigrantes em 1847. No total, cerda de 321 mil alemães deixaram a Europa no período entre 1844 e 1847 . Nos dois quadriênios seguintes, a migração alemã intercontinental foi ainda maior, totalizando quase 353 mil emigrantes entre 1848 e 1851, e mais de 628 mil pessoas entre 1852 e 1855 (Ferenczi; Willcox, 1929, p. 686-696). Pressão do excedente da população rural sobre a terra, deterioração dos direitos dos camponeses, crises agrícolas, escassez de alimentos, fome e pobreza extrema foram as principais razões da migração de quase 1,38 milhão de alemães no período de 1840 a 1855 (Ferenczi; Willcox, 1929; Walker, 1964; Rürup, 1992; Kautsky, 1968; Hobsbawm, 2016).

Para muitos governos alemães, a migração intercontinental foi a solução para se livrar da massa de trabalhadores pobres desempregados e de camponeses miseráveis e insatisfeitos, os quais representavam uma ameaça latente à ordem social em uma época marcada por movimentos revolucionários. É o que indica o editorial do Illustrirte-Zeitung de 3 de maio de 1851: "é certo que, graças à emigração, a redução da força de trabalho pode multiplicar e facilitar o ganho daqueles que ficam, e essa convicção também fez com que, de modo geral, se avistasse a emigração como um meio oportuno contra a pobreza". Assim sendo, conforme o periódico, quem deveria emigrar eram as pessoas pertencentes à classe mais baixa da população, desempregados e indivíduos sem recursos, pessoas "que pesam em grande número sobre a pátria, por isso, o afastamento destes é importante para benefício deles próprios e da pátria". Em seguida, o editorial adverte que "se a terra natal deseja livrar-se de uma parte da classe mais pobre, a fim de reduzir os riscos sociais provocados pelo crescimento excessivo do proletariado", ela também precisa orientar a emigração, uma vez que "só se pode esperar um resultado favorável da emigração, se emigrarem somente aqueles que não dispõem de recursos [...]" (IZ, 1851, p. 281-282). 
$\mathrm{Na}$ ausência de instituições governamentais para organizar e dirigir a emigração alemã, na década de 1840 surgiram nos estados alemães várias associações comerciais e civis de apoio e fomento à emigração. Uma das principais associações criadas nessa época foi a Kolonisations-Verein von 1849 in Hamburg (Associação de Colonização de 1849 em Hamburgo), a maior firma estrangeira de colonização a atuar no Brasil no século XIX. Em 1851, essa firma fundou, na região nordeste de Santa Catarina, a colônia Dona Francisca, hoje município de Joinville, um dos maiores e mais importantes núcleos de colonização alemã do Brasil no século XIX (Ficker, 1965; Fouquet, 1974; Richter, 1983; Schneider, 1983; Schröder, 2003; Ferreira, 2019).

Entre 1850 e 1888, a Associação de Colonização de 1849 em Hamburgo $(\mathrm{ACH})$ encaminhou mais de 17 mil colonos de língua alemã à colônia Dona Francisca, número que representa quase 20\% do total de imigrantes de origem alemã que desembarcaram no Brasil nesse perío$\mathrm{do}^{1}$. Além do transporte de colonos, por mais de quarenta anos a $\mathrm{ACH}$ explorou o comércio de terras na colônia Dona Francisca, que, após sua expansão, cobriu uma área que compreende os atuais municípios de Joinville, Campo Alegre, Guaramirim, São Bento do Sul, Araquarie Jaraguá do Sul (Ferreira, 2019).

Embora a $\mathrm{ACH}$ tenha transportado colonos de língua alemã para o Brasil e negociado terras no país durante quase toda segunda metade do século XIX, este artigo foca a análise na trajetória da empresa colonizadora no período de 1846 a 1855. O objetivo de delimitar o estudo a esse decênio é captar quais as razões que levaram um grupo composto de grandes negociantes, armadores, banqueiros e políticos de Hamburgo a se reunir para promover e organizar a colonização do sul do Brasil, mais especificamente da província de Santa Catarina, bem como compreender porque em 1855 a ACH foi liquidada, reorganizada e reconstituída com o mesmo nome.

As principais fontes utilizadas neste estudo são os relatórios da direção da $\mathrm{ACH}$, correspondências e ofícios trocados entre os empresários hamburgueses, memorandos e petições encaminhados pelos dirigentes da

A tradução literal do nome da empresa colonizadora (Kolonisations-Verein von 1849 in Hamburg) é Associação de Colonização de 1849 em Hamburgo. Entretanto, em vários documentos primários e na literatura em geral a tradução aparece como Sociedade Colonizadora de 1849 em Hamburgo. 
empresa colonizadora ao governo brasileiro. A partir dessas fontes, este artigo expõe o interesse e os objetivos dos empresários de Hamburgo na colonização do sul do Brasil. Ainda, são apresentadas evidências que questionam um pensamento bastante difundido na historiografia: o de que a colônia Dona Francisca foi, desde o início, um empreendimento modelo, bem-sucedido, independente de grandes favores do governo brasileiro por ser um negócio privado, organizado e dirigido por uma importante associação de empresários alemães (Oberacker Jr., 1965; Miltenberg, 1852; Schramm, 1964a; Ternes, 1981).

Apolinário Ternes, por exemplo, destaca o "senso de organização" do empresário e senador de Hamburgo Christian Matthias Schröder, fundador da $\mathrm{ACH}$, que, conforme Ternes, "planejou, organizou e executou um dos mais ambiciosos projetos de emigração e de colonização da América Latina através da implantação da Colônia Dona Francisca". O autor ainda ressalta as "bases empresariais" e o "caráter particular" do empreendimento colonial Dona Francisca, que, nas palavras de Ternes (1981), foi um "empreendimento modelar", uma "pequena Alemanha" em terras brasileiras (Ternes, 1981, p. 35, 86, 93-94, 119).

Da mesma forma, em seu estudo sobre a "Colônia Alemã Dona Francisca”, Percy Ernst Schramm afirma: "Se alguma vez houve uma colonização alemã, que ocorreu conscientemente, com cautela e benevolência, em maior escala e em proporção aos meios disponíveis para o investimento pretendido, é este o caso" (Schramm, 1964a,p. 316).Também Miltenberg escreveu: "nunca houve um empreendimento tão cuidadosamente preparado, cautelosamente iniciado e conscienciosamente dirigido como a Colônia Dona Francisca, a pérola do Brasil” (Miltenberg, 1852, p. 16).

Não obstante, este artigo demonstra que, não fosse o apoio financeiro do governo brasileiro, a $\mathrm{ACH}$ não teria sido capaz de continuar com o seu projeto de colonização no sul do Brasil. O estudo ainda mostra a decisiva interferência de François d'Orléans, príncipe de Joinville, casado com a princesa Dona Francisca, irmã de D. Pedro II, que utilizou suas relações pessoais com o cunhado para requerer o apoio do governo brasileiro à $\mathrm{ACH}$, empresa da qual o príncipe de Joinville passou a ser sócio a partir de 1855 .

O artigo divide-se em seis seções além desta introdução. A primeira seção analisa o interesse dos empresários de Hamburgo na colonização 
do sul do Brasil. A segunda seção examina o plano de colonização e as negociações dos empresários hamburgueses com o governo brasileiro. A terceira seção apresenta as condições do acordo firmado entre Christian Matthias Schröder e o príncipe de Joinville, proprietário de 25 léguas quadradas de terras (40 mil hectares) na região nordeste de Santa Catarina. Pelo contrato assinado em Hamburgo, em 5 de maio de 1849, o príncipe cedeu parte dessas terras a Christian Matthias Schröder, que, em seguida, constituiu a ACH com a finalidade de colonizar e comercializar as terras contratualmente concedidas pelo príncipe de Joinville. A quarta seção expõe o programa de colonização da $\mathrm{ACH}$, que, além dos lucros com a venda de terras na colônia Dona Francisca, oferecia aos seus acionistas os ganhos potenciais com a organização e transporte de imigrantes alemães para o sul do Brasil e o futuro comércio entre a colônia e Hamburgo. A quinta seção demonstra que as expectativas da $\mathrm{ACH}$ foram excessivamente otimistas e, não fosse a decisiva interferência do príncipe de Joinville e o auxílio financeiro do governo brasileiro, a empresa colonizadora naufragaria poucos anos depois da sua fundação. Por fim, são apresentadas as conclusões deste estudo.

\section{O interesse dos empresários de Hamburgo na colonização do sul do Brasil}

Depois da independência do Brasil, em 1822, o comércio do país com Hamburgo, à época o principal entreposto comercial da Europa continental, ganhou impulso e rapidamente a cidade alemã se transformou em importante porto de entrada das exportações brasileiras na Europa (Baasch, 1892; Minnemann, 1977; Schneider, 1983; Richter, 1983; Schröder, 2003; Lenz, 2008). Porém, a diferença na tarifa de importação, de $14 \%$ para os produtos ingleses e $24 \%$ para as mercadorias alemãs, não permitia a estas competirem com aqueles, o que levou o cônsul de Hamburgo na Bahia, Peter Peycke, a intervir e solicitar a D. Pedro I as mesmas condições alfandegárias concedidas às nações mais favorecidas da Europa, especialmente à Inglaterra. Em março de 1826, Peycke entregou a D. Pedro I uma exposição na qual destacou as "grandes e inegáveis vantagens que as Cidades Hanseáticas, mormente o porto de Hamburgo, oferecem 
ao Brasil", pois, "não tendo a Alemanha colônias próprias, cujas produções possam gozar ali de preferência" os gêneros do Brasil, "mediante um direito igual para todas as nações", encontrariam nos portos hanseáticos "vantagens que nenhuma outra nação da Europa oferece, existindo pelo contrário muitas que, para favorecerem suas colônias e navegação, usam de um sistema ou motivo proibitório e nocivo ao Brasil" (Peycke, 1826 apud Minnemann, 1977, p. 19-24).

Em resposta, D. Pedro I afirmou que não poderia ser concedido igual tratamento tarifário às Cidades Hanseáticas sem a assinatura de um acordo comercial. Assim, logo o síndico de Hamburgo, Karl Sieveking, deu início às negociações que resultaram na assinatura do "Tratado de Comércio e Navegação entre os Senados das Cidades Livres e Hanseática de Lübeck, Bremen e Hamburgo e o Brasil", em 17 de novembro de 1827. A partir de então, cresceu o número de negociantes e firmas comerciais alemãs no Brasil. Em 1821, existiam apenas seis grandes casas de comércio germânicas no Rio de Janeiro; em 1830 já eram 20; em 1844, esse número subiu para 25, e para 50 em 1850. Nessa época, Porto Alegre, São Paulo e Santos também contavam com importantes empresas teutas de importação e exportação, dentre as quais se encontra a firma Theodor Wille \& Cia., uma das principais exportadoras de café do Brasil no século XIX, com filiais no Rio de Janeiro, São Paulo e Santos (Schneider, 1983; Oberacker Jr., 1985; Lenz, 2008).

A maior presença de negociantes e casas de comércio alemãs no Brasil contribuiu para intensificar as relações comerciais entre o país e Hamburgo; em 1841, um a cada três navios que aportavam naquela cidade alemã tinha como origem o Brasil. Açúcar, peles, café, tabaco e cacau eram os principais produtos brasileiros exportados. Em contrapartida, o país importava dos estados alemães, via porto de Hamburgo, tecidos diversos, mobílias, teares, queijo, papel, entre outras mercadorias industrializadas.

A Figura 1 a seguir apresenta o balanço comercial entre Brasil e Hamburgo no período 1836-1848. Nota-se que nesse intervalo de tempo o resultado do balanço do comércio hamburguês-brasileiro foi bastante favorável ao Brasil. Merece destaque o fato de que as exportações de Hamburgo para o Brasil representaram em média 29\% das importações no período entre 1836 e 1848 . Como três quartos da diferença do saldo do balanço comercial eram pagos à vista, havia uma grande e constante 
saída de capitais de Hamburgo, o que levou um grupo composto de grandes negociantes, armadores, banqueiros e políticos hamburgueses a se reunir para elaborar um plano que viesse a melhorar a situação comercial da cidade alemã em relação ao Brasil (Schneider, 1983; Richter, 1983).

Figura1 - Balanço comercial do Brasil em relação a Hamburgo, 1836-1848(valores em marcos hamburgueses)

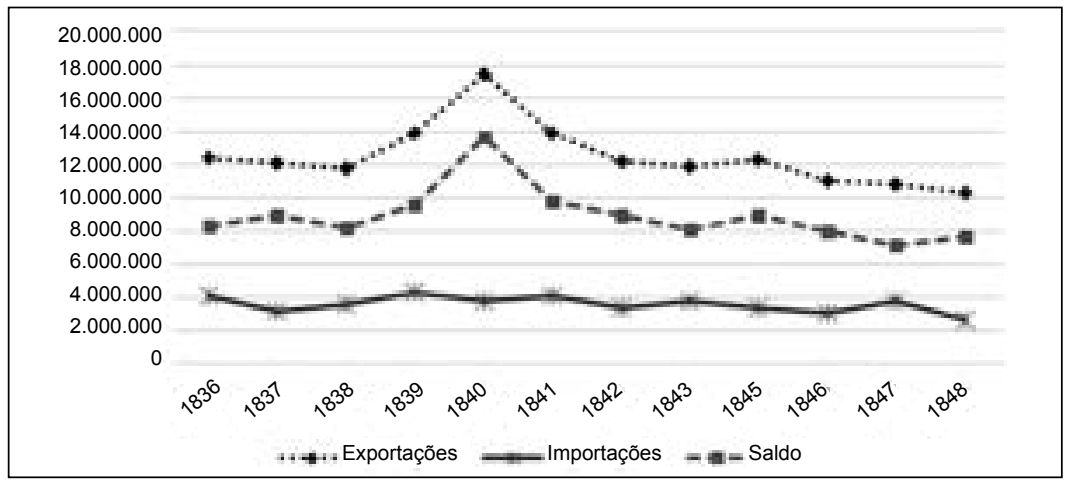

Fontes: Elaboração do autor com base nos dados publicados em Müller (1845, p. 68), Richter (1983, p. 78); Einfuhr und Ausfuhr Hamburg - Brasilien, 1845-1860. Fotocópia no AHJ. Coleção Memórias da Cidade.

$\mathrm{Na}$ época, o transporte marítimo de imigrantes constituía um grande negócio, e os comerciantes e armadores de Bremen, cidade vizinha e principal concorrente comercial de Hamburgo, estavam obtendo lucros apreciáveis com o transporte de emigrantes de língua alemã para a América do Norte. Os Estados Unidos eram o principal destino dos emigrantes alemães, os quais, na sua grande maioria, dirigiam-se ao país norte-americano a partir do porto de Bremen (Ferenczi; Willcox, 1929; Walker, 1964; Richter, 1983). Observando os resultados alcançados pelos negociantes de Bremen, os empresários de Hamburgo resolveram controlar parte do transporte marítimo de emigrantes alemães dirigindo a emigração alemã para a América do Sul, especialmente para o Brasil, pois, conforme o síndico de Hamburgo, Sieveking, "o transporte de emigrantes para o Brasil poderia ganhar tanta importância para os armadores hamburgueses, quando conquistou para Bremen o transporte de imigrantes para os Estados Unidos" (Sieveking apud Delbrück, 1896, p. 152).

Com o apoio do Senado e da Câmara de Comércio de Hamburgo 
e de autoridades brasileiras, notadamente do cônsul geral do Brasil na Prússia, Johann Jacob Sturz, e do então embaixador brasileiro em Berlim, visconde de Abrantes, vinte das pessoas e firmas de comércio política e economicamente mais importantes de Hamburgo formaram, em 27 de maio de 1846, a Associação Provisória para a Proteção da Emigração Alemã para o Brasil ${ }^{2}$. Entre os membros dessa associação estava o senador hamburguês Christian Matthias Schröder, proprietário da firma de comércio e navegação Christian Matthias Schröder \& Co., que, durante a primeira metade do século XIX, desempenhou papel importante no comércio entre Brasil e Hamburgo, importando, principalmente, café e açúcar (Schneider, 1983; Richter, 1983, 2004).Além disso, Schröder atuou como representante dos senadores Nicolau de Campos Vergueiro e Francisco Antônio de Souza Queiroz no engajamento de colonos europeus, como se constata no anúncio publicado na edição de 3 de outubro de 1850 do Neue Zürcher Zeitung (NZZ):

Famílias ou pessoas que desejam emigrar encontram acolhimento e abrigo seguro sob condições bastante vantajosas nas colônias alemãs situadas nas terras do príncipe de Joinville e dos senhores senadores Vergueiro e Queiroz na província de São Paulo no Brasil. Navios otimamente equipados, com passagens baratas, são regularmente expedidos por Christian Matthias Schrödere Comp. em Hamburgo. (NZZ, 1850, p. 1220)

Nessa época, a firma Christian Matthias Schröder \& Co. organizava e transportava imigrantes europeus para o Brasil, onde mantinha uma filial, no Rio de Janeiro. Esta era dirigida pelo terceiro filho de Christian Matthias Schröder e cônsul geral de Hamburgo no Brasil, Hermann Schröder, que, em 3 de agosto de 1846, apresentou o projeto de colonização da Associação Provisória para a Proteção da Emigração Alemã

2 Além de Christian Matthias Schröder, pertenciam à Associação Provisória: Adolph Schramm, Robert M. Sloman, Ernest Merck, da firma H. J. Merck \& Co., Salomon Heine, Carl L. D. Meister, Aug. F. Söhne, Ferdinand Blass \& Schomburger, C. F. Johns Söhne, Ross Vidal \& Co., Wachsmuth \& Krogmann, A. Halle, Emanuel \& Filhos, C. F. Johns, Albrecht \& Dill, F. F.Tesdorpf \&Filhos, Hochgreve \& Vorwerk, F. Lacisz, Anth. Died. Schröder, A. Abendroth D., C. Woermann. Conforme "Plan für das Komitee zur Bildung eines Vereins zum Schutz..., 27/05/1846" (Documentos do Arquivo da Fundação Hanseática. Seção Colonização Brasileira. S/599 Nr. 74,2 rot. Câmara de Comércio de Hamburgo, Alemanha). 
para o Brasil ao ministro Joaquim Marcelino de Brito ${ }^{3}$.Veja-se a seguir o plano da associação hamburguesa.

\section{O plano de colonização dos empresários hamburgueses}

Apresentada ao governo brasileiro em 3 de agosto de 1846, a proposta da Associação Provisória para a Proteção da Emigração Alemã para o Brasil previa a criação de grandes colônias agrícolas nas províncias do Rio Grande do Sul e Santa Catarina, onde seriam estabelecidos cerca de 40 mil colonos alemães ao longo de vinte anos. Para tanto, os empresários hamburgueses requeriam do governo brasileiro a concessão gratuita de grandes e contínuas extensões de terras naquelas províncias, devendo essas terras serem bem-localizadas e apropriadas à agricultura e ao comércio. Os empresários solicitavam, ainda, isenção de impostos; pagamento de um prêmio de 15 mil-réis para cada colono maior de 10 anos de idade que fosse introduzido no Brasil; livre importação de materiais de construção, mantimentos, ferramentas e utensílios dos imigrantes durante o primeiro ano; dispensa dos colonos do serviço militar; liberdade de culto e livre constituição municipal às futuras colônias ${ }^{4}$.

Enquanto aguardava a tramitação da sua proposta no Conselho de Estado, a associação hamburguesa, por intermédio do cônsul Schröder, contratou Hermann Bruno Otto Blumenau, que recém havia apresentado seu plano particular de colonização ao governo brasileiro. Os empresários hamburgueses desejavam aproveitar a experiência do Dr. Blumenau, que, após obter recomendações do cônsul J. J. Sturz e do embaixador visconde de Abrantes, partiu de Hamburgo com destino ao Rio Grande do Sul, onde chegou em 20 de junho de 1846.Após permanecer algumas semanas na província rio-grandense, Dr. Blumenau possuía informações mais precisas, resultantes da avaliação in loco da situação da colonização

3 "Vorstellung des Herrn Schröder bei der brasilianischen Regierung, 3/08/1846";" Schreiben Schröder an Komitee, 4/08/1846" (Documentos do Arquivo da Fundação Hanseática. Seção Colonização Brasileira. S/599 Nr. 74,2 rot. Câmara de Comércio de Hamburgo, Alemanha).

4 "Plan für das Komitee, 27/05/1846" (Documentos do Arquivo da Fundação Hanseática. Seção Colonização Brasileira. S/599 Nr. 74,2 rot. Câmara de Comércio de Hamburgo, Alemanha). 
alemã no sul do Brasil, bem como das possibilidades de criação de estabelecimentos coloniais no Rio Grande do Sul. Por sua vez, os empresários hamburgueses tinham apenas as informações que lhes eram transmitidas pelos seus contatos no Rio de Janeiro e os dados contidos em relatórios oficiais, estes nem sempre precisos (Richter, 2004; Voigt, 2004; Nicoceli, 2014).

Para Dr. Blumenau, não havia possibilidade de o projeto da Associação de Hamburgo ser aprovado. Ele ponderava que os empresários hamburgueses teriam que "desistir de prêmios em dinheiro e tornar a causa [colonização] a mais fácil possível” (Blumenau, 1846 apud Voigt, 2004, p. 43). Ainda assim, Dr. Blumenau buscou apoio político para a proposta hamburguesa, sob o argumento de que Hamburgo possuía muitos negócios com o Brasil.

Em meio às discussões e articulações sobre o projeto de colonização dos empresários hamburgueses, a Associação Provisória para a Proteção da Emigração Alemã para o Brasil foi definitivamente constituída, passando a se chamar Sociedade de Promoção da Emigração Alemã para o Sul do Brasil. Esta logo obteve o apoio dos ministros Manuel Antonio Galvão e Holanda Cavalcanti d'Albuquerque, que auxiliaram na reformulação do plano original, apresentado em 3 de agosto de 1846 pelo cônsul Hermann Schröder e que ainda aguardava tramitação (Schneider, 1983; Richter, 1983; Voigt, 2004; Ferreira, 2019).

A 26 de novembro de 1846, a sociedade hamburguesa apresentou nova proposta ao ministro Joaquim Marcelino de Brito, requerendo, em vez da concessão gratuita, a venda de duas extensas porções de terras no Rio Grande do Sul e em Santa Catarina, cada uma contendo de 25 a 30 léguas quadradas. Entretanto, os empresários hamburgueses insistiam em obter subvenções do governo brasileiro, argumentando que, sem elas, não seria possível empreender a colonização alemã em larga escala no Brasil ${ }^{5}$.Vale notar, em meados do século XIX, aproximadamente $90 \%$ dos emigrantes alemães dirigiam-se preferencialmente aos Estados Unidos (Ferenczi; Willcox, 1929; Walker, 1964). Ante a essa forte concor-

5 “Vorstellung der Herren Schröder und Schramm an die brasilia-nische Regierung"; "Motive $z u$ dem im November 1846 entworfenen hbg. Kolonisationsplan"; "Schreiben Komitee an Schröder, 27/11/1846" (Documentos do Arquivo da Fundação Hanseática. Seção Colonização Brasileira. S/599 Nr. 74,3 rot. Câmara de Comércio de Hamburgo, Alemanha). 
rência, a sociedade hamburguesa considerava os subsídios do governo brasileiro imprescindíveis à lucratividade da empresa colonizadora ${ }^{6}$.

Enquanto aguardavam o parecer do Conselho de Estado, os dirigentes da sociedade hamburguesa começaram a negociar com o príncipe de Joinville, que, pelo seu casamento com a princesa Dona Francisca, havia recebido, como parte do dote nupcial, 25 léguas quadradas de terras na província de Santa Catarina ${ }^{7}$. Essas terras, segundo os dirigentes hamburgueses, reuniam todos os requisitos favoráveis à colonização alemã. Por outro lado, os empresários de Hamburgo esperavam obter, por intermédio do príncipe de Joinville, devido às suas relações pessoais com o cunhado, D. Pedro II, e aos interesses econômicos da Família Real, os favores considerados indispensáveis à empresa colonizadora (ACH, 1851). Convém salientar que, desde o início, o auxílio financeiro do governo brasileiro foi visto como condição sine qua non ao projeto de colonização dos empresários hamburgueses (Ferreira, 2019).

A falta de entendimento entre o príncipe de Joinville e os dirigentes da Sociedade de Hamburgo travou as negociações. O príncipe, esperando lucrar com a valorização das terras adjacentes, dispôs-se a conceder apenas cinco das 25 léguas quadradas de terras que formavam seu patrimônio na província de Santa Catarina. A proposta não agradou aos empresários hamburgueses, que, diante do seu projeto de dirigir a emigração alemã em grande escala para o Brasil, desejavam colonizar pelo menos quatro quintos das terras do príncipe. Em meio às negociações com o príncipe de Joinville, os empresários receberam a notícia que seu projeto não encontrou apoio suficiente no Conselho de Estado, que sequer aceitou discutir a proposta hamburguesa. Os dirigentes da

6 "Schreiben des Herrn Schramm an Ko-mitee, 22/03/1847"; "Schreiben Schramm an Komitee, 31/03/1847"; "Schreiben Schramm an Komitee, 4/05/1847" (Documentos do Arquivo da Fundação Hanseática. Seção Colonização Brasileira. S/599 Nr. 74,3 rot. Câmara de Comércio de Hamburgo).

7 "Contrato de casamento de S. A. R. o Príncipe de Joinville com S. A. R a Senhora Princesa Dona Francisca Carolina", celebrado em 22/04/1843. BR SCAHJ CF 12, cx 1, prat. 36; "Entwurfeiner Übereinkunft mit dem Prinzen von Joinville"; "Brief des Komitees betr. Landerwerben vom Prinzen von Joinville"; "Verhandlungsvollmacht des Komitees für Herrn Genaut, 20/02/1847”; "Schreiben des Komitees an Herrn Genaut, Paris, 26/03/1847”; "Schreiben des Komitees an Genaut, Febr. 1847” (Documentos do Arquivo da Fundação Hanseática. Seção Colonização Brasileira. S/599 Nr. 74,1 rot. Câmara de Comércio de Hamburgo, Alemanha). 
Sociedade de Hamburgo alteraram o projeto novamente e reapresentaram-no ao Conselho de Estado. Este, porém, rejeitou definitivamente a proposta da Sociedade, alegando que, antes de definir os princípios básicos da política de terras e colonização do Brasil, o que incluía delimitar as terras devolutas, não avaliaria os projetos de colonização de companhias estrangeiras ${ }^{8}$.

Pouco tempo depois estourou a revolução liberal de 1848 na França, que derrubou Luís Felipe I, rei da França, pai do príncipe de Joinville. Resignado, Luís Felipe refugiou-se com sua família em Claremont, na Inglaterra, onde permaneceu exilado. Em fevereiro de 1849, diante da aflitiva situação financeira da família, o príncipe de Joinville enviou Louis François Léonce Aubé a Hamburgo para negociar parte das suas terras na província de Santa Catarina com a Sociedade de Promoção da Emigração Alemã para o Sul do Brasil. Esta, porém, havia sido dissolvida em 1848, devido à instabilidade política e às incertezas resultantes dos levantes revolucionários que atingiram os estados alemães em março daquele ano (Ficker, 1965; Schneider, 1983; Richter, 1983).

Em Hamburgo, Aubé encontrou o senador Christian Matthias Schröder, um dos signatários da extinta sociedade, que procurou reconstituir a associação para dar início às negociações. Embora não tenha obtido êxito na sua iniciativa de reorganizar a Sociedade de Promoção da Emigração Alemã para o Sul do Brasil, Schröder estava convicto de que os membros da extinta sociedade se recusaram a formar nova associação tão somente devido às circunstâncias e instabilidades da época. Assim, o próprio Schröder assumiu as negociações com o representante do príncipe de Joinville, que o autorizou a repassar a uma sociedade por ações a tarefa de colonizar as terras que estavam sendo negociadas, sob a condição de que o senador Schröder ficasse à frente da futura empresa (ACH, 1851).

\section{O contrato com o príncipe de Joinville}

A 5 de maio de 1849, reuniram-se, em Hamburgo, Louis François

8 "Schreiben Schramm an Komitee, 12/06/1847"; "Schreiben Schröder an Komitee, 5/08/1847";" Schreiben Schramm an Komitee, 14/09/1847”. Documentos do Arquivo da Fundação Hanseática. Seção Colonização Brasileira. S/599 Nr. 74,2 rot. Câmara de Comércio de Hamburgo, Alemanha. 
Léonce Aubé, como procurador do príncipe e da princesa de Joinville, e Christian Matthias Schröder, para celebrar o contrato pelo qual os príncipes cederam oito das suas 25 léguas quadradas de terras localizadas na província de Santa Catarina. Ficou acertado que, se o governo brasileiro não aceitasse pagar uma subvenção para as passagens dos colonos com idade entre 6 e 12 anos, os príncipes concederiam mais uma légua quadrada de terra a Schröder, que, nesse casso, receberia o total de nove léguas quadradas (14.400 hectares) de terras. Os príncipes de Joinville ainda prometiam negociar com Schröder outras 12 léguas quadradas (19.200 hectares) de terras, a um preço fixo de 10 francos por hectare, as quais Schröder deveria aceitar ou recusar dentro do prazo de quatro anos. Independentemente do tamanho da concessão, o contrato reservava ao príncipe de Joinville um terreno de cinco hectares na área urbana e 500 hectares de terras no distrito rural da futura colônia Dona Francisca, bem como as minas que viessem a ser encontradas na área da concessão?.

É importante notar que, inicialmente, o príncipe de Joinville concedeu a Christian Matthias Schröder apenas oito das 25 léguas quadradas de terras que formavam seu patrimônio em Santa Catarina, reservando para si o direito de explorar as 17 léguas restantes. O valor dessas terras, afirmou o príncipe de Joinville, aumentaria "em virtude do crescimento da população e dos escoadouros de mercadorias e vias de comunicação que esta população promoverá” (Joinville, 1855). Com essa perspectiva, o príncipe impôs uma série de condições para ceder as oito léguas quadradas de terras a Schröder, dentre elas, a obrigação de preparar a infraestrutura necessária à recepção dos colonos e fornecer a eles os meios indispensáveis à sua subsistência e prosperidade, o que incluía a construção de escolas, igrejas e hospitais ${ }^{10}$.

Reconhecendo a necessidade de assentar os colonos de maneira ordenada, Schröder comprometeu-se a introduzir na futura colônia 1,5 mil imigrantes dentro do prazo de cinco anos, dos quais 100 colonos adultos deveriam chegar nos primeiros quinze meses, 200 nos nove meses seguintes e 400 em cada um dos três anos restantes. Schröder prometeu

9 "Contrato de cessão de parte das terras dotais firmado entre o Príncipe de Joinville e Christian Matthias Schröder”. BR RJIHGB Lata 216, doc. 21.

10 "Contrato de cessão de parte das terras dotais firmado entre o Príncipe de Joinville e Christian Matthias Schröder”. BR RJIHGB Lata 216, doc. 21. 
recepcionar e fornecer alojamento, ferramentas, sementes e alimentos a todos os colonos durante os dois primeiros anos, contados a partir da chegada da primeira leva de imigrantes. $O$ contrato ainda determinava que Christian Matthias Schröder deveria solicitar imediatamente ao governo brasileiro os favores considerados indispensáveis à colonização das terras de Dona Francisca, e que eram usualmente conferidos aos empreendimentos coloniais do país. De outra parte, o príncipe e a princesa de Joinville se comprometeram a "fazer uso de todas as suas influências para consegui-los”. Caso os privilégios fossem negados, Schröder ficava livre para renunciar ao contrato ${ }^{11}$.

Consumado o acordo em Hamburgo, Léonce Aubé dirigiu-se a Londres, onde o contrato foi ratificado pelos príncipes de Joinville em 28 de maio de 1849. Em seguida, Christian Matthias Schröder reuniu-se com Adolf Schramm e Georg Wilhelm Schröder para formar a Kolonisations-Verein von 1849 in Hamburg.

\section{O plano da Associação de Colonização de 1849 em Hamburgo}

Em 11 de agosto de 1849, a direção provisória da $\mathrm{ACH}$, presidida pelo senador hamburguês Christian Matthias Schröder, dirigiu ao governo brasileiro uma petição com uma série de concessões em favor da colônia que se pretendia estabelecer na província de Santa Catarina, nas terras dos príncipes de Joinville, sublinhando que estes tinham interesse e apoiavam o empreendimento colonial hamburguês. A petição desdobrava-se em dez itens em que se requeriam: isenção aos imigrantes de toda e qualquer contribuição tributária durante os primeiros dez anos, dispensa dos colonos do serviço militar, auxílio para o pagamento das passagens dos imigrantes com idade entre 5 e 12 anos, criação de uma alfândega e mesa de rendas no porto de São Francisco do Sul, isenção de taxas portuárias para os navios empregados no transporte de imigrantes, liberdade de culto, livre constituição municipal, tendo os colonos o direito de escolher entre eles seus árbitros e representantes, isenção de impostos

11 "Contrato de cessão de parte das terras dotais firmado entre o Príncipe de Joinville e Christian Matthias Schröder”. BR RJIHGB Lata 216, doc. 21. 
alfandegários para todos os utensílios, mobílias, ferramentas, sementes e alimentos necessários à instalação e sustento dos colonos, proibição do emprego do trabalho escravo na colônia (ACH, 1849).

Enquanto aguardava a decisão do governo brasileiro, a direção provisória da $\mathrm{ACH}$ publicou, em Hamburgo, os estatutos da empresa. $\mathrm{O}$ primeiro parágrafo do regimento destacava as condições e qualidades das terras onde seria estabelecida a colônia Dona Francisca, e deixava claro o objetivo da empresa: colonizar inicialmente oito, depois mais doze, em um total de vinte léguas quadradas de terras em Santa Catarina, concedidas contratualmente pelos príncipes de Joinville. Ainda conforme o regimento da empresa, a comercialização de terras na colônia Dona Francisca constituiria a principal fonte de receita da $\mathrm{ACH}$. Logo, a demarcação dos lotes, a garantia dos direitos individuais, sobretudo no que diz respeito à propriedade privada e à liberdade comunal e religiosa, a construção de estradas, escolas, hospitais e igrejas, todas garantias previstas no primeiro parágrafo do estatuto da empresa, faziam parte das condições que permitiriam à $\mathrm{ACH}$ atrair para a futura colônia o maior número possível de imigrantes e, deste modo, promover a valorização das terras da colônia Dona Francisca. Somente assim a ACH poderia gerar os ganhos prometidos aos seus acionistas ( $\mathrm{ACH}, 1851)$.

Para iniciar suas operações, a ACH estimava vender mil ações no valor de 200 marcos hamburgueses ou 100 táleres prussianos cada uma, cuja soma formaria o fundo da Associação, que seria considerada definitivamente constituída a partir da subscrição de 800 ações. O investidor que adquirisse ações da $\mathrm{ACH}$ podia optar por trocar cada ação adquirida por um terreno de 12,5 hectares na área rural da futura colônia. Caso quisesse abrir mão do seu número de ações para investir diretamente na exploração da terra na colônia, o acionista deveria comunicar à direção da empresa e assumir o compromisso de colonizar a propriedade recebida no prazo de dois anos, com pelo menos uma família de colonos (ACH, 1851).

$\mathrm{Na}$ hipótese de não realizar a colonização no tempo estipulado, o acionista perderia todos os direitos sobre as terras que recebeu e ainda lhe seriam debitados $25 \%$ das parcelas pagas por ação, ou seja, 50 marcos hamburgueses. Os acionistas poderiam, em substituição aos 12,5 hectares rurais, optar pela posse de dois lotes de $2.500 \mathrm{~m}^{2}$ cada, ambos localizados na futura "Cidade de Joinville", núcleo urbano da colônia Dona 
Francisca. Neste caso, ficava dispensada a obrigação de colonização. Os acionistas que recebessem a escritura definitiva das terras deveriam devolver suas ações à empresa colonizadora, mas continuariam com o direito de receber dividendos $(\mathrm{ACH}, 1851)$.

Em 15 de maio de 1850, o Decreto Imperial no 537 aprovou praticamente todos os favores e privilégios requeridos pela direção provisória da associação hamburguesa na petição de 11 de agosto de 1849 (Brasil, 1850). Com as garantias do governo brasileiro, a direção da $\mathrm{ACH}$, em reunião pública realizada em Hamburgo, a 11 de março de 1851, convidou todos os interessados no negócio da emigração a se associarem por meio da subscrição de ações no valor de 200 marcos hamburgueses cada, com depósito inicial de 20\%. Prometia-se aos futuros acionistas um ganho de $50 \%$ em cinco anos, o que seria obtido com a venda de mil terrenos de $2.500 \mathrm{~m}^{2}$ estrategicamente reservados em local onde seria fundada a "Cidade de Joinville", mais 13.250 hectares de terras a serem vendidas na área rural da colônia Dona Francisca (ACH, 1851).

Ponto importante a observar é a separação rigorosa entre a área rural da colônia Dona Francisca e a "Cidade de Joinville". Conforme relatório da direção da $\mathrm{ACH}$, a zona rural e as terras mais afastadas do centro da colônia seriam colonizadas primeiro, pois, deste modo, seria possível elevar o valor dos lotes mais próximos ao local reservado à futura cidade "devido a sua localização privilegiada para a venda de produtos, sendo o suficiente para permitir e justificar a futura elevação do preço”( $\mathrm{ACH}$, 1851). Assim, a direção da empresa colonizadora estipulou o preço do morgo de terra em 2 táleres prussianos, o equivalente a $9 \$ 600$ por hectare, para os terrenos mais afastadas do centro da colônia, acreditando não ser preciso vender mais de 3.750 hectares a este preço para, em seguida, elevar o preço daquelas terras para $14 \$ 400$ o hectare ${ }^{12}$. Na área destinada à fundação da cidade de Joinville, foram reservados 500 lotes de terras contendo $2.500 \mathrm{~m}^{2}$, que, inicialmente, deveriam ser vendidos a $6 \$ 000$, valor que, segundo o relatório de 1851, "qualquer pessoa assumiria"; e outros 500 terrenos, igualmente com $2.500 \mathrm{~m}^{2}$, a $30 \$ 000$ (ACH, 1851). Os dirigentes da Associação de Colonização justificavam a significativa diferença entre os preços dos terrenos devido "à grande variedade de

121 morgo de terra $\approx 2.500 \mathrm{~m}^{2} ; 1$ hectare $=10.000 \mathrm{~m}^{2} ; 1$ táler prussiano $=1 \$ 200 \mathrm{em}$ 1852. 
vantagens que a localização privilegiada da colônia pode oferecer" (ACH, 1852).

É importante salientar que a venda de terras aos colonos era apenas parte da estratégia comercial dos empresários hamburgueses, cujo objetivo primordial foi lucrar com a organização e transporte de imigrantes e exportação de gêneros agrícolas tropicais. Nota-se, porém, que a direção da Associação de 1849, ao contrário da sociedade formada em 1846 e extinta em 1848, não explicitou, em seus estatutos, os objetivos de controlar parte do transporte de imigrantes alemães e explorar o futuro comércio entre a colônia Dona Francisca e Hamburgo. Tais objetivos são, no entanto, evidentes no primeiro relatório da $\mathrm{ACH}$, dirigido especialmente aos empresários interessados em investir na empresa. Conforme o relatório, para ampliar as relações comerciais com os estados alemães, fazia-se necessário colonizar terras cujo clima fosse propício ao cultivo de produtos como algodão, tabaco, café, cana de açúcar e erva mate," porque caso se quisesse conduzir a colonização a um lugar de clima semelhante ao nosso, no qual os produtos não sejam muito diferentes dos nossos, ir-se-ia gerar concorrência ao invés de troca e ao invés de aumentar o comércio, diminuí-lo". O relatório também ressaltava as vantagens da proximidade da colônia Dona Francisca com o "suntuoso porto de São Francisco" e as possibilidades que as terras do planalto de Curitiba, vizinhas, ofereciam ao comércio com o interior do Brasil (ACH, 1851).

Assim, não por acaso, os primeiros empresários que se associaram ao grupo fundador da Associação de Colonização de 1849 foram os comerciantes Ernst Merck e Friedrich Gültzow, ambos vinculados ao comércio importador e exportador do Brasil. Pouco tempo depois, pelo menos sete firmas comerciais, agências e companhias de navegação alemãs, todas ligadas ao comércio com o Brasil, tornaram-se acionistas da $\mathrm{ACH}$. Eram elas: Robert M. Sloman, Knöhr \& Burchard, N. O. Bieber, August Bolten, Joh. Berenberg-Gossler \& Cia., J. C. Godeffroy \& Filhos, F. Laeisz. Até 12 de junho de 1851, quando o diretor geral da ACH, Georg W. Schröder, comunicou a integralização das 800 ações necessárias à definitiva constituição da empresa, 76 pessoas e empresas haviam adquirido 843 ações da Associação, sendo a firma Schröder \& Co. a principal acionista, com 300 ações (Richter, 1983; Ferreira, 2019).

Os navios empregados no transporte dos colonos embarcados em Hamburgo com destino à colônia Dona Francisca não pertenciam à 
ACH. Esta fretava as embarcações de seus acionistas ou por intermédio deles, os quais estavam envolvidos com o comércio marítimo e transporte de imigrantes de europeus para o Brasil. São os casos das firmas Schröder \& Co., Robert M. Sloman, August Bolten, J. C. Godeffroy \& Filhos, Knöhr \& Burchard e N.O. Bieber (Richter, 1983). Essas duas últimas firmas, associadas a outras três empresas alemãs, constituíram, em 1855, a Companhia Hamburgo-Brasileira de Navegação a Vapor, antecessora da Companhia Hamburgo-sul-americana de Navegação a Vapor (Hamburg Süd), hoje uma das maiores empresas de transporte marítimo de contêineres do mundo ${ }^{13}$. Aliás, algumas das firmas que se associaram à $\mathrm{ACH}$ em meados do século XIX ainda existem, enquanto outras foram extintas não há muito tempo. Por exemplo, a companhia de navegação F. Laeisz ainda está ativa, com escritórios no Japão,Alemanha e Filipinas ${ }^{14}$. A firma H.J. Merck \& Cia., fundada no final do século XVIII, encerrou suas atividades na década de 1980, depois de atuar no comércio, navegação e no setor financeiro de Hamburgo, tendo participado, em 1856, de um consórcio de empresas que fundaram o Norddeutsche Bank, na época o maior banco mercantil de Hamburgo (Wulff, 1906; North, 1997). Entre as firmas participantes desse consórcio, estava a Joh. Berenberg-Gossler \& Cia., proprietária do Berenberg Bank, que, ao lado das firmas H. J. Merck \& Cia., F. Laeisz e A. Bolten, todas acionistas da ACH, fundaram a Hamburg America Line (HAPAG), uma das maiores companhias de navegação da Alemanha. O Berenberg Bank está atualmente entre os maiores bancos de investimento do mundo, com escritórios em Hamburgo, Zurique, Frankfurt, Londres, Nova Iorque e Londres ${ }^{15}$.

A Schröder \& Co., principal acionista da ACH, foi criada em 1767 pelo burgomestre Christian Matthias Schröder. Quando este faleceu, em 1821, seus filhos e sobrinhos dirigiam os escritórios da empresa em Hamburgo, Bremen, Amsterdã, Riga, São Petersburgo e Londres. Com a morte do burgomestre Schröder, coube ao seu filho, Christian Matthias Schröder, senador de Hamburgo de 1821 a 1858, assumir a empresa. Entre 1821 e 1856, a Schröder \& Co. multiplicou suas operações com a criação de filiais em Trieste, Liverpool, Nova Orleans, Nova Iorque, Rio

\footnotetext{
13 Hamburg Süd: <https://hamburgsud.com>.

14 F. Laeisz: <https://laeisz.de/unternehmen/historie $>$.

15 Berenberg Bank: <https://berenberg.de/en/>.
} 
de Janeiro e Lima. Além dessas, havia as empresas de membros da família em Quakenbrück, Jacarta e Singapura, cujos negócios estavam ligados à Schröder \& Co. Em Londres, Johann Heinrich Schröder, irmão do senador Schröder, representava os negócios da família atuando no comércio de commodities agrícolas. Em 1818, Johann fundou, em Londres, sua própria empresa, a J. H. Schröder \& Co., abrindo filiais em Hamburgo e Liverpool. Com o capital acumulado decorrente da importação e exportação de açúcar, café, índigo e algodão, a J. H. Schröder \& Co. passou a financiar a construção de ferrovias e o comércio, tornando-se, em seguida, um dos principais bancos de investimentos de Londres. A J. H. Schröder \& Co. também figurava entre as acionistas da ACH (Roberts, 1992; Schramm, 1964b; Ferreira, 2019).

Explica-se assim o fato de a direção da ACH especificarem seus estatutos apenas seus objetivos quanto à comercialização das terras de Dona Francisca. A verdade é que, para levantar rapidamente o capital necessário ao cumprimento das obrigações assumidas com o príncipe de Joinville, os diretores da $\mathrm{ACH}$ reservaram aos futuros acionistas da empresa o transporte de imigrantes e a possibilidade de comércio entre a futura colônia e Hamburgo. Essa estratégia, por um lado, distribuía os riscos do capital imobilizado nas obras iniciais e necessárias à fundação da colônia Dona Francisca e, por outro, garantia ganhos imediatos aos acionistas da empresa, uma vez que a venda de terras aos colonos poderia gerar lucros somente a mais longo prazo.

Portanto, a ACH constituiu-se como uma grande empresa comercial que previa obter retorno com a comercialização das terras de Dona Francisca e que, além dos lucros com a venda de terrenos na colônia, oferecia aos seus acionistas os ganhos potenciais com a organização e transporte de imigrantes alemães para o sul do Brasil e o futuro comércio importador e exportador que os colonos da Dona Francisca poderiam proporcionar. Logo, porém, ficou evidente que as expectativas e os cálculos dos empresários hamburgueses foram excessivamente otimistas e, não fosse a interferência do príncipe de Joinville e o auxílio financeiro do governo brasileiro, a ACH naufragaria poucos anos depois da sua fundação, como será demonstrado a seguir. 


\section{O apoio do governo brasileiro à Associação de Colonização de 1849 em Hamburgo}

Em reunião pública realizada em Hamburgo, em 11 de março de 1851, a direção da $\mathrm{ACH}$ apresentou aos seus acionistas e interessados as estimativas de receitas e despesas para os cinco primeiros anos da empresa. Pelos cálculos dos dirigentes da Associação, ao longo do quinquênio 1851-1855, seriam gastos um total de 243 mil marcos hamburgueses na colonização das terras da Dona Francisca, sendo 75 mil (30,9\%) destinados aos investimentos de infraestrutura (alojamentos provisórios, estradas, pontes, caminhos, armazém, escolas, igrejas e hospital), 50 mil (20,6\%) para adiantamentos aos colonos, e 45 mil $(18,5 \%)$ para pagamento dos salários do diretor e demais funcionários da colônia. Foram previstos ainda 36 mil (14,8\%) para despesas diversas e imprevistas, 20 mil (8,2\%) para gastos administrativos dos escritórios de Hamburgo e do Rio de Janeiro, 6 mil (2,5\%) em subvenções para o pagamento de parte dos vencimentos dos sacerdotes, professores e médicos, 8 mil $(3,3 \%)$ para as despesas com passagens dos funcionários da $\mathrm{ACH}$ e 3 mil marcos (1,2\%) com utensílios, ferramentas e mobílias necessárias à instalação da direção da colônia (ACH, 1851).

No que diz respeito à receita, a principal fonte de recursos da $\mathrm{ACH}$ seria a venda de terras aos colonos imigrantes, que, conforme as estimativas, renderia 318 mil marcos hamburgueses. Esse montante seria o resultado da venda de mil terrenos de $2.500 \mathrm{~m}^{2}$ localizados na área urbana da colônia, mais 13.250 hectares de terras a serem vendidas na zona rural da Dona Francisca. Também foram previstos ganhos com a venda de algumas edificações e com o recebimento dos adiantamentos feitos aos colonos, o que, segundo projeções, alcançaria a soma de 75 mil marcos.

A Tabela 1 a seguir apresenta uma síntese das estimativas de receitas e despesas da ACH para o período 1851-1855. Nota-se que para esse quinquênio há previsão de distribuição de lucros no valor de $150 \mathrm{mil}$ marcos hamburgueses, o que equivalia a um ganho de $50 \%$ ou de 100 marcos por ação em cinco anos. Esse resultado, diziam os dirigentes da $\mathrm{ACH}$, "nos parece mais do que suficiente, já que o empreendimento dificilmente estará sujeito a uma perda real, pois, uma fraca venda de terras, que só pode ser consequência da fraca imigração, fará com que os custos também sejam menores" (ACH,1851). Por outro lado, segundo 
os dirigentes da empresa, na eventualidade de uma venda mais lenta dos terrenos, os custos, calculados sobre o empreendimento em sua totalidade, poderiam em parte ser distribuídos em um período maior. Em todo o caso, ponderava a direção da Associação de Colonização, "quase não se pode admitir dúvidas de que o ganho terá que crescer a cada ano com o progresso da colonização e de que o empreendimento pode ser expandido muito além de seus limites atuais [...], porque as terras que fazem fronteira com a colônia, pertencem em parte ao príncipe de Joinville e em grande parte ao governo brasileiro" e ambos, asseguravam os dirigentes hamburgueses, tinham interesse no avanço da colonização. Assim, essas terras, “com condições muito favoráveis, poderão ser adquiridas a cada expansão da sociedade" (ACH, 1851).

Tabela 1 - Projeção das receitas e despesas da Associação de Colonização, 1851-1855 (valores em marcos hamburgueses)

\begin{tabular}{|c|c|c|c|}
\hline \multicolumn{2}{|l|}{ DÉBITO } & \multicolumn{2}{|l|}{ Crédito } \\
\hline Investimento em infraestrutura & 75.000 & Venda de mil lotes urbanos & 30.000 \\
\hline Adiantamentos aos colonos & 50.000 & $\begin{array}{l}\text { Venda de } 13.250 \text { hectares de } \\
\text { terras rurais }\end{array}$ & 288.000 \\
\hline Honorários & 45.000 & $\begin{array}{l}\text { Ganhos sobre vendas e } \\
\text { adiantamentos }\end{array}$ & 30.000 \\
\hline Despesas diversas e imprevistas & 36.000 & $\begin{array}{l}\text { Adiantamento devolvido com } \\
10 \% \text { de perdas }\end{array}$ & 45.000 \\
\hline Despesas administrativas & 20.000 & & \\
\hline Passagens para funcionários & 8.000 & & \\
\hline Subvenções & 6.000 & & \\
\hline Ferramentas e mobiliários & 3.000 & & \\
\hline Resultado presumido & 150.000 & & \\
\hline Total & 393.000 & Total & 393.000 \\
\hline
\end{tabular}

Fonte: Primeiro Relatório da ACH, março de 1851. Tradução Helena Remina Richlin. AHJ.

Apesar do otimismo da direção da Associação de Colonização, nota-se que, embora as terras concedidas à empresa representassem uma reserva importante de valor, elas não tinham liquidez imediata para financiar os investimentos e as despesas previstas para a colonização inicial da Dona Francisca. Além disso, ao contrário do projetado, após um ano, foram gastos mais de 38,1 mil marcos com transporte, preparativos para 
recepção e hospedagem dos colonos e quase 26,5 mil marcos com alimentação e adiantamentos aos colonos. Portanto, já no primeiro ano, foi despendido mais da metade do montante previsto para essas duas despesas no período de 1851 a 1855. Também foram gastos pouco mais de 8 mil marcos com móveis e material de escritório, passagens e subvenções para os funcionários da $\mathrm{ACH}$. Ao todo, foram gastos $73 \mathrm{mil}$ marcos no primeiro ano, o equivalente a $30 \%$ do valor total projetado para o período de 5 anos, sem que houvessem sido providenciados alguns dos investimentos previstos no contrato com o príncipe de Joinville, como, por exemplo, a construção de escolas e igrejas (ACH, 1852).

Ao mesmo tempo, até 31 de dezembro de 1851 a venda de 828 ações injetou na empresa colonizadora um capital de 46,1 mil marcos hamburgueses. Portanto, somente no primeiro ano, a $\mathrm{ACH}$ acumulou um déficit de 26,9 mil marcos. Nessas circunstâncias, em maio de 1852, a direção da empresa comunicou aos acionistas que "por mais que a nossa situação financeira prometa desenvolver-se, o nosso ativo é formado basicamente por estimações e não há, no momento, como arcar com as demais exigências previstas em nosso primeiro relatório" (ACH, 1852). Dois anos depois, J. C. Nagel, procurador da Associação de Colonização de Hamburgo no Rio de Janeiro, expôs a preocupante situação da colonização da Dona Francisca ao ministro Pedro de Araújo Lima, visconde de Olinda. Nagel ressaltou que, sem o auxílio financeiro do governo brasileiro, não seria possível cumprir a segunda parte do contrato firmado com o príncipe de Joinville, que consistia na aquisição e colonização das 12 léguas quadradas de terras vizinhas à colônia Dona Francisca (Nagel, 1854).

Conforme J. C. Nagel, o não cumprimento dessa segunda etapa do projeto não resultaria em multas ou penalidades à associação hamburguesa; advertiu, porém, que o fracasso da colonização das terras da Dona Francisca, caso faltasse o apoio do governo brasileiro, causaria repercussão negativa nos principais centros de emigração europeia, principalmente na Alemanha, provocando prejuízos à colonização e modernização do Brasil (Nagel, 1854). Dessa forma, ACH pressionava o governo brasileiro para obter o auxílio financeiro necessário à manutenção de seu empreendimento colonial na província de Santa Catarina.

Para embasar o pedido de apoio da empresa colonizadora, J. C. Nagel encaminhou ao visconde de Olinda uma pró-memória assinada pelo 
diretor gerente da ACH, Friedrich Gültzow.Trata-se, ipsis litteris, de uma exposição "confidencial, franca e exata dos trabalhos da Sociedade Colonizadora de 1849 em Dona Francisca, das quantias expendidas por ela e dos resultados da experiência dos primeiros três anos da sua gestão". Conforme o documento, até 20 de outubro de 1853 a ACH havia vendido 1.028 ações a 200 marcos hamburgueses cada, levantando assim um capital de 205.600 marcos. Desse valor, a ACH tinha gasto 129.235 marcos com a colonização das primeiras nove léguas quadradas de terras, restando em seus cofres 76.365 marcos hamburgueses, o equivalente a 45:600\$000 (Gültzow, 1853).

Conforme Friedrich Gültzow, a ACH contava ainda com 22:985\$551 em dívida dos colonos e esperava arrecadar 172:140\$000 com a venda de 11.476 hectares de terras na colônia, o que gerava uma expectativa de receita de 195:125\$551. Porém, ponderava Gültzow, a cobrança feita aos colonos exigia cautela e a medição, demarcação e venda dos terrenos requeriam tempo, o que poderia exceder os prazos contratualmente estabelecidos pelo príncipe de Joinville. Dessa forma, na realidade, a $\mathrm{ACH}$ dispunha de apenas 45:600\$000 para executar as obras de que a colônia mais necessitava, avaliadas em 40:000\$000, e cobrir as despesas com a remessa e estabelecimento dos 417 colonos que faltavam para cumprir a primeira parte do contrato com o príncipe de Joinville, o que, pelos cálculos da direção da $\mathrm{ACH}$, custaria 31:275\$000 (Gültzow, 1853).

Para empreender na segunda fase do projeto de colonização da Dona Francisca, Gültzow calculava serem necessários 274:700\$000, dos quais 67:200\$0000 seriam para a aquisição das 12 léguas quadradas de terras do príncipe de Joinville, 187:500\$000 para colonizar essas terras com pelo menos 2,5 mil imigrantes e 20:000 $\$ 000$ para cobrir metade dos custos de construção e manutenção das estradas, igrejas, escolas e hospitais. Assim, ao todo, a ACH precisava investir ao menos 345:975\$000 para prosseguir e expandir a colonização da Dona Francisca, sendo necessário desembolsar, no curto prazo, 138:475\$000. A empresa, entretanto, possuía apenas um terço desse capital em seus cofres (Gültzow, 1853). Portanto, a ACH não dispunha de capital suficiente disponível para sequer finalizar a primeira etapa da colonização da Dona Francisca, muito menos para empreender na segunda fase do projeto.

Para contornar esse problema e manter o seu projeto colonizador no sul do Brasil, os empresários hamburgueses ofereceram ao governo imperial 
brasileiro 1.500 ações da $\mathrm{ACH}$, que seriam subscritas pelo valor total de 187:5000\$000. Aceitando essa proposta, o governo passaria a controlar $50 \%$ da ACH. Friedrich Gültzow argumentava que aquelas ações ofereciam garantias suficientes pela posse e venda das terras aos colonos da Dona Francisca, as quais, segundo ele, tenderiam a subir de valor à medida que o número de colonos com plena propriedade de terras aumentasse (Gültzow, 1853).

A direção da $\mathrm{ACH}$ projetava a expansão da colonização da colônia Dona Francisca com a aquisição das 12 léguas quadradas de terras do príncipe de Joinville e introdução de mais 4 mil colonos, o que exigia um investimento total de 367:200\$000. Friedrich Gültzow ponderava que, naquele momento, as 21 léguas quadradas de terras, que antes nada valiam, estavam avaliadas em 504:000\$000. Assim, Gültzow garantia ao governo um resultado positivo de 136:800 $\$ 000$, ainda com o acréscimo de 80:000\$000 relativo ao pagamento dos adiantamentos feitos aos colonos, o que elevava o resultado do balanço para 216:800\$000 (Gültzow, 1853).

Apesar dos resultados prometidos e das considerações temerárias a respeito dos efeitos nefastos que o fracasso da colônia Dona Francisca provocaria à colonização do Brasil, o governo brasileiro não aceitou a proposta dos empresários hamburgueses e, excetuando as concessões previstas no Decreto de 15 de maio de 1850, não ofereceu nenhum auxílio à ACH. Assim, logo a colônia Dona Francisca entrou em crise.

Sem a ajuda do governo brasileiro, o empreendimento estava fadado ao fracasso, conforme relata o príncipe de Joinville em carta dirigida ao conselheiro e mordomo da Casa Imperial, Paulo Barbosa da Silva, em 9 de fevereiro de 1855. Na correspondência, o príncipe revela grande preocupação com o futuro da colônia, onde ele havia aplicado parte de seus recursos na expectativa de lucrar com a valorização das terras que ainda lhe pertenciam. Dizia o príncipe de Joinville:

O futuro de minhas propriedades é, em miniatura, o futuro do Brasil. Se a colonização europeia se dirigir nessa direção, o futuro do Brasil estará assegurado.As circunstâncias são favoráveis. [...] Mas os homens são crianças. Para que ocorra um grande movimento, é preciso um chefe para assumir o comando, para pôr-se à frente, que por sua vez conduza os demais. Poder-se-ia iniciar o movimento de imigração e sustentá-lo até que esteja bem 
desenvolvido e possa avançar por si. É preciso que os que devem recrutar os colonos e transportá-los obtenham nessa operação benefícios imediatos suficientes. Falo intencionalmente imediato. Com efeito nos tempos normais os negociantes contentavam-se, quando uma transação é segura, com vantagens sucessivas. Assim, a casa de Hamburgo com a qual eu havia contratado a colonização, contentava-se, a princípio, com a remuneração representada por concessões de terras, com as quais ela contava especular e auferir lucros futuros. Hoje em dia, ainda que já exista na colônia um núcleo populacional que confere certo valor às terras que nada valiam, ela se recusa a continuar a transação e continuá-la nas condições em que fora estabelecida.Vejo-me assim ameaçado de ver interrompida a corrente imigratória e, talvez, em consequência declina e padeça o começo de colônia que havíamos formado. (Joinville, 1855)

Temendo os prejuízos que poderiam advir caso a $\mathrm{ACH}$ abandonasse seu empreendimento colonial em Santa Catarina, o príncipe de Joinville pediu ao conselheiro Paulo Barbosa que conversasse com "pessoas entendidas" e que "inspirassem confiança" para que fosse possível obter meios de "manter e continuar com a empresa da colonização, no momento ameaçada de naufrágio" (Joinville, 1855). As preocupações e solicitações do príncipe foram imediatamente transmitidas a D. Pedro II, que, após fazer breves considerações a respeito da política de colonização do Império, comunicou ao conselheiro Paulo Barbosa ter conversado com o ministro Luiz Pedreira do Coutto Ferraz sobre o pedido de Joinville, e ele tinha se comprometido a ver com os colegas o que se podia fazer (Pedro II, 1855).

Logo depois, em abril de 1855, chegou à colônia Dona Francisca o diretor da Repartição Geral de Terras Públicas, Manoel Felizardo de Souza e Mello, que, após permanecer por seis semanas na colônia, emitiu parecer favorável às solicitações da $\mathrm{ACH}$. Mais tarde, a 13 de junho de 1855, reconhecendo "que o progresso de Dona Francisca se retardava, e que o mau resultado que dali proviesse tinha de influir poderosamente contra a colonização em geral", o governo brasileiro contratou com a $\mathrm{ACH}$, mediante subvenção, a introdução de 2.250 imigrantes na colônia Dona Francisca (Brasil, 1856, p. 23-25). Pelo contrato, a ACH comprometia-se a estabelecer aquele número de colonos dentro do prazo de três anos, manter casas de recepção para abrigo provisório de pelo menos duzentos imigrantes, dar alimento por oito dias aos mais 
pobres, conseguir-lhes trabalho remunerado por pelo menos seis meses e abrir ruas e estradas que servissem de comunicação entre os colonos (ACH, 1855; Brasil, 1856).

Em contrapartida, o governo brasileiro se comprometeu a conceder um prêmio de 30 mil-réis para cada colono entre 10 e 45 anos de idade que fosse introduzido na colônia, e de 20 mil-réis para menores entre 5 e 10 anos. O governo também prometeu financiar a construção de escolas e das igrejas católica e protestante, comprometendo-se, inclusive, a pagar os salários dos sacerdotes de ambas as confissões e dos professores do ensino elementar. O governo assumiu, ainda, os custos de manutenção das pontes e da construção de uma estrada que ligasse a colônia ao planalto do Paraná através da Serra Geral, que viria a ser a espinha dorsal do comércio da Dona Francisca (ACH, 1855; Brasil, 1856).

Ao mesmo tempo, o governo brasileiro garantiu que, depois de finalizada a Estrada da Serra, seria facultada à $\mathrm{ACH}$ a aquisição de duas léguas quadradas de terras localizadas no planalto paranaense, pelo preço de meio Real a braça quadrada. Nesse caso, a Associação obrigava-se a estabelecer dois mil colonos na região, com a ajuda de prêmios idênticos ao anteriormente mencionado. $\mathrm{O}$ governo também assegurou à empresa colonizadora a preferência na aquisição de mais 16 léguas quadradas de terras vizinhas àquelas duas léguas quadradas, desde que a ACH confirmasse o desejo de colonizá-las pelos mesmos favores. Finalmente, o governo prometeu prorrogar, por mais de três anos, os favores concedidos à $\mathrm{ACH}$ por meio do Decreto de 15 de maio de $1850(\mathrm{ACH}$, 1855; Brasil, 1856).

Também naquela data de 13 de junho de 1855, mediante a mesma subvenção por imigrante introduzido, o governo brasileiro contratou com Léonce Aubé, procurador do príncipe de Joinville, a importação e a fixação, dentro do prazo de cinco anos, de 4 mil colonos nas terras que ainda pertenciam ao príncipe. Nessas condições, o príncipe de Joinville enviou Léonce Aubé a Hamburgo para firmar um novo acordo com a ACH, cuja assinatura se deu em 23 de novembro de 1855 (ACH, 1855; Brasil, 1856). Pelo novo contrato, a empresa colonizadora abdicava do direito de compra das 12 léguas quadradas de terras contratualmente asseguradas pelo príncipe de Joinville, que naquela data, por intermédio do seu procurador, Léonce Aubé, adquiriu 800 ações nominais da $\mathrm{ACH}$, mediante o pagamento de 100 mil marcos e a cessão 
de 7.500 hectares de terras à empresa. Ao mesmo tempo, liquidou-se a Associação de Colonização de 1849 em Hamburgo, sendo seus ativos e passivos transferidos a uma nova sociedade, fundada naquele ato com o mesmo nome. Nessa nova empresa, em cumprimento às exigências do príncipe de Joinville, Léonce Aubé foi incluído como membro da direção e assumiu também o cargo de diretor da colônia Dona Francisca (Ficker, 1965; Schneider, 1983; Richter, 1983; Ferreira, 2019).

Com essa nova configuração societária e administrativa e o auxílio financeiro do governo brasileiro, a $\mathrm{ACH}$ deu início à segunda fase de colonização da Dona Francisca, que se transformou em um dos maiores e mais importantes núcleos de colonização alemã do Brasil no século XIX. Não obstante, o senador Manoel de Assis Mascarenhas afirmou, no Senado, que a colônia Dona Francisca só prosperava porque contava com o auxílio do príncipe de Joinville e proteção do governo brasileiro (Brasil, 1859, p. 114). Críticas como essas não abalaram a confiança da $\mathrm{ACH}$ em relação ao governo brasileiro, ao qual a direção da empresa expressava "profundo sentimento de gratidão à repetida prova de magnanimidade" e "lealdade" (ACH, 1860).

A generosidade e lealdade do governo brasileiro à $\mathrm{ACH}$ foram demonstradas várias vezes, com a concessão de favores e privilégios acertados em sucessivos contratos assinados entre 1855 e 1888. Além da ajuda financeira, por meio desses contratos, o governo brasileiro assegurou à ACH o monopólio da venda das terras localizada na colônia Dona Francisca, que, após sua expansão, cobriu uma área que compreende os atuais municípios de Joinville, Jaraguá do Sul, Araquari, Guaramirim, São Bento do Sul e Campo Alegre. Não obstante, na segunda metade da década de 1880, a ACH estava novamente em crise, em decorrência da qual, em maio de 1890, a empresa suspendeu seus planos de colonização em Santa Catarina.

\section{Conclusão}

As evidências apresentadas neste artigo demonstram que a principal motivação dos empresários hamburgueses para elaborar um projeto de colonização do sul do Brasil em meados do século XIX foi a perspectiva de ampliar o comércio hamburguês-brasileiro, bem como obter ganhos 
com o crescente e importante negócio do transporte de imigrantes alemães. Foram esses os objetivos primordiais que levaram vinte das pessoas e firmas comerciais mais importantes de Hamburgo, muitas delas com negócios no Brasil, a se reunirem, em 1846, para organizar a Sociedade de Promoção da Emigração Alemã para o Sul do Brasil. Com o apoio de importantes autoridades brasileiras, do Senado e da Câmara de Comércio de Hamburgo, os empresários hamburgueses planejavam criar grandes colônias agrícolas nas províncias do Rio Grande do Sul e Santa Catarina, onde os colonos, estabelecidos como pequenos proprietários rurais, deveriam produzir, principalmente, gêneros agrícolas de exportação.

Naquele mesmo ano de 1846, os empresários hamburgueses apresentaram ao governo brasileiro um plano de colonização no qual requeriam uma série concessões e benefícios. Não obtendo êxito nas suas negociações com o governo, os empresários hamburgueses passaram a negociar com o príncipe de Joinville, cujo patrimônio em terras na província de Santa Catarina reunia, segundo os empresários, todos os requisitos favoráveis à colonização alemã e à produção de gêneros de exportação, como algodão, tabaco, café e cana de açúcar. Por outro lado, os hamburgueses esperavam obter, por intermédio do príncipe de Joinville, devido às suas relações pessoais com D. Pedro II, os favores considerados indispensáveis à empresa colonizadora.

Consumado o acordo com o príncipe de Joinville, os empresários hamburgueses organizaram a Associação de Colonização de 1849 em Hamburgo, que prometia aos seus acionistas um ganho de 50\% em cinco anos, o equivalente a 100 marcos hamburgueses por ação. Além disso, a $\mathrm{ACH}$ oferecia aos seus acionistas os ganhos potenciais com a organização e transporte de imigrantes e o futuro comércio importador e exportador que os colonos poderiam proporcionar. Não por acaso, os primeiros acionistas da $\mathrm{ACH}$ foram grande negociantes, agências e companhias de comércio e navegação com estreitas relações comerciais com o Brasil. Entre essas empresas, encontram-se firmas comerciais e bancos de investimentos que controlavam importantes corporações e estavam ligados ao alto círculo financeiro e comercial da Europa no século XIX, o que revela o grande negócio que era o transporte de emigrantes europeus na época e o tamanho das expectativas em relação à colônia Dona Francisca.

Não obstante, já em 1854, ou seja, apenas cinco anos após a sua fundação, a ACH, por intermédio do seu representante no Rio de Janeiro, 
J. C. Nagel, comunicou ao governo brasileiro as dificuldades financeiras da empresa colonizadora e solicitou auxílio para continuar investindo na colonização das terras de Dona Francisca. Depois do apelo do príncipe de Joinville, o governo brasileiro firmou seu primeiro contrato com a ACH, assinado em junho de 1855. A partir de então, o governo assumiu papel fundamental na colonização da Dona Francisca, que continuou sendo organizada e dirigida pela $\mathrm{ACH}$.

Em conclusão, não fosse a decisiva interferência do príncipe de Joinville em 1855 e o permanente apoio do governo brasileiro, a $\mathrm{ACH}$ não teria sido capaz de continuar com o seu projeto de colonização em Santa Catarina. Esse fato merece ser destacado, pois contradiz um pensamento amplamente difundido na historiografia: o de que a colônia Dona Francisca, um dos maiores e mais importantes núcleos de colonização alemã do Brasil no século XIX, foi, desde o início, um empreendimento modelo, bem-sucedido, independente de grandes favores do governo brasileiro por ser um negócio privado, organizado e dirigido por uma importante sociedade de empresários alemães.

\section{Referências}

ARQUIVO HISTÓRICO DE JOINVILLE (AHJ). Coleção Memórias da Cidade. Einfuhr und Ausfuhr Hamburg - Brasilien, 1845-1860. Joinville, 1845-1860.

ARQUIVO DA FUNDAÇÃO HANSEÁTICA. Diversos documentos sobre colonização brasileira. Hamburgo, Alemanha: Câmara de Comércio de Hamburgo.

ASSOCIAÇÃO DE COLONIZAÇÃO DE 1849 EM HAMBUR GO (ACH). Relação das concessões que pede a Sociedade Colonizadora estabelecida em Hamburgo ao Governo de Sua Majestade o Imperador do Brasil, 11 de agosto de 1849. BR RJIHGB Lata 216, doc. 21. Rio de Janeiro: Instituto Histórico e Geográfico do Brasil.

ASSOCIAÇÃO DE COLONIZAÇÃO DE 1849 EM HAMBURGO (ACH). Relatórios da Direção de 1851. Tradução Helena Remina Richlin. Joinville: AHJ.

ASSOCIAÇÃO DE COLONIZAÇÃO DE 1849 EM HAMBURGO (ACH). Relatórios da Direşão de 1852. Tradução Helena Remina Richlin. Joinville: AHJ.

ASSOCIAÇÃO DE COLONIZAÇÃO DE 1849 EM HAMBURGO (ACH). Relatórios da Direção de 1855. Tradução Helena Remina Richlin. Joinville: AHJ.

ASSOCIAÇÃO DE COLONIZAÇÃO DE 1849 EM HAMBURGO (ACH). Relatórios da Direção de 1860. Tradução Helena Remina Richlin. Joinville: AHJ.

BAASCH, Ernst. Beiträge zur Geschichte der Handelsbeziehungen zwischen Hamburg und Amerika. Hamburg: L. Friederischen \& Co., 1892. 
BLUMENAU, Hermann. Carta do Dr. Blumenau a Johann J. Sturz, 14 de setembro de 1846. In:VOIGT, André Fabiano. Cartas reveladas: a troca de correspondências entre Hermann Blumenau e Johann Jacob Sturz. Blumenau: Cultura em Movimento, 2014.

BRASIL. Câmara dos Deputados. Colleção das Leis do Imperio do Brasil. Decreto n 537 de 15 de maio de 1850.Tomo XI. Parte I, p. 23. Rio de Janeiro:Typ. Nacional, 1850. Disponível em: <https://www2.camara.leg.br/atividade-legislativa/legislacao/ colecao-anual-de-leis $>$. Acesso em: 8 maio 2020.

BRASIL. Ministério do Império. Relatório apresentado à Assembléia Geral Legislativa na Quarta Sessão da Nona Legislatura pelo Ministro e Secretário de Estado dos Negócios do Império Luiz Pedreira do Couto Ferraz. Rio de Janeiro:Typographia Nacional, 1856.

BRASIL. Senado Federal. Anais do Senado do Imperio do Brasil, sessão de 14 de junho de 1859, Livro 1.Rio de Janeiro: Typ. do Correio Mercantil, 1859. Disponível em: $<$ https://www.senado.leg.br/publicacoes/anais/asp/IP_AnaisImperio_digitalizados. asp>. Acesso em: 8 maio 2020.

DELBRÜCK, Hans. Preussische Jahrbücher. 86 Band. Berlin: Stilke, 1896.

FERENCZI, Imre; WILLCOX, Walter F. International migrations, v. 1: Statistics. Nova York: NBER Books, 1929.

FERREIRA, Luiz Mateus da Silva. Terra, trabalho e indústria na colônia de imigrantes Dona Francisca (Joinville), Santa Catarina, 1850-1920. São Paulo: FFLCH/USP, 2019 (Tese de Doutorado em História Econômica).

FICKER, Carlos. História de Joinville: subsídios para a crônica da colônia Dona Francisca. Joinville: Imp. Ipiranga, 1965.

FOUQUET, Carlos. O imigrante alemão. São Leopoldo, FCC 25 de julho. São Paulo: Instituto Hans Staden, 1974.

GÜLTZON, Friedrich. Pró-memória para servir de apoio à petição da Sociedade Colonizadora Hamburguesa, 20 de outubro de 1853. BR RJIHGB Lata 216, doc. 21. Rio de Janeiro: Instituto Histórico e Geográfico Brasileiro.

HOBSBAWM, E. J. A era das revoluções, 1789-1848. Rio de Janeiro: Paz e Terra, 2016.

ILLUSTRIRTE-ZEITUNG, Leipzig, n. 409, 3 maio 1851 (Cópia no AHJ).

JOINVILlE, Príncipe de. Carta do Príncipe de Joinville ao Conselheiro Paulo Barbosa, datada de Claremont, 9 de fevereiro de 1855. APB - Tomb. 3133-97. Petrópolis: Museu Imperial/Ibram/Ministério da Cidadania.

JOINVILLE, Príncipe de. Contrato de cessão de parte das terras dotais firmado entre o Príncipe de Joinville e Christian Matthias Schröder. BR RJIHGB Lata 216, doc. 21. Rio de Janeiro: Instituto Histórico e Geográfico Brasileiro.

KAUTSKY, Karl. A questão agrária. Rio de Janeiro: Laemmert, 1968.

LENZ, Sylvia Ewel. Alemães no Rio de Janeiro: diplomacia e negócios, profissões e ócios (1815-1866). Bauru: Edusc, 2008.

MILTENBERG, R. J. Die Deutsche Kolonie Dona Francisca in der südbrasilischen Provinz Santa Catharina. Berlin: Fr. Schneider \& Comp., 1852.

MINNEMANN, Herbert. Tratado de comércio e navegação entre os senados das cidades livres 
e hanseáticas de Lübeck. Bremen e Hamburgo e Sua Majestade o Imperador do Brasil, assinado no Rio de Janeiro em 17 de novembro de 1827. Hamburgo: Instituto de Estudos Ibero-americanos, 1977.

MÜLlER, A. Karl. Statistisches Jahrbuch für 1845. Verlag der I. C. Hinrichsschen Buchhandlung. Leipzig, 1845.

NAGEL, J. C. Pró-memória para o Visconde de Olinda, 8 de maio de 1854. BR RJIHGB Lata 216, doc. 21. Joinville: Arquivo Histórico de Joinville, 1854.

NEUE ZÜRCHER ZEITUNG, n. 276, 3 out. 1850 (Cópia no AHJ).

NICOCELI, Vanessa. Hermann Blumenau: uma experiência de colonização em Santa Catarina (1846-1884). Curitiba:UFPR, 2014 (Dissertação de Mestrado em História).

NORTH, Michael. The great german banking houses and international merchants, sixteenth to nineteenth century. In:TEICHOVA, Alice; HENTENRYCK, Ginette Kurgan-van; ZIEGLER, Dieter (Org.). Banking, trade and industry: Europe, America and Asia from the thirteenth to the twentieth century. U.K: Cambridge University, 1997.

OBERACKER JR., Carlos Henrique. Joinville: Fundação Hamburguesa, Revista de História, v. 31, n. 64, p. 427-431, 1965.

OBERACKER JR., Carlos Henrique. A contribuição teuta à formação da nação brasileira, v. II. Rio de Janeiro: Presença, 1985.

PEDRO II, Dom. Mensagem de D. Pedro II a Paulo Barbosa (1855). In: LACOMBE, Américo L. J. O mordomo do imperador. Rio de Janeiro: Biblioteca do Exército, 1994.

PEYCKE, Peter. Exposição do cônsul hamburguês na Bahia, Peter Peycke, à Sua Majestade o Imperador D. Pedro I, 22 de março de 1826. In: MINNEMANN, Herbert. Tratado de comércio e navegação entre os senados das cidades livres e hanseáticas de Lübeck. Bremen e Hamburgo e Sua Majestade o Imperador do Brasil, assinado no Rio de Janeiro em 17 de novembro de 1827. Hamburgo: Instituto de Estudos Ibero-americanos, 1977.

RICHTER, Klaus. A fundadora de Joinville: sociedade colonizadora de 1849 em Hamburgo. Revista do Instituto Histórico e Geográfico de Santa Catarina, $3^{\text {a }}$ fase, n. 4, 1983.

RICHTER, Klaus. Os primórdios da colonização sistemática alemã em Santa Catarina: 1846-1848. Revista do Instituto Histórico e Geográfico de Santa Catarina, n. 23, 2004.

ROBERTS, Richard. Schroder's: Merchants \& Bankers. London: Macmillan, 1992.

RÜRUP, Reinhard. Deutschland im 19.Jahrhundert, 1815-1871. Göttingen:Vandenhoeck \& Ruprecht, 1992.

SCHNEIDER, Adolfo Bernardo. Povoamento, imigração e colonização: a fundação de Blumenau e de Joinville. Joinville: edição do autor, 1983.

SCHRAMM, E. Percy. Die Deutshe Siedlungskolonie Dona Franscisca (Brasilien: St. Catharina) Im Rahmen Gleichzeitiger Projekte und Verhandlungen. Jahrbuch für Geschichte Lateinamerikas, v. 1. Hamburg University Press, 1964a.

SCHRAMM, E. P. Neun Generationen: dreihundert Jahre deutscher Kulturgeschichte im Lichte der Schicksale einer Hamburger Bürgerfamilie (1648-1948), v. 2. Vandenhoeck \& Ruprecht, 1964b. 
SCHRÖDER, Ferdinand. A imigração alemã para o sul do Brasil até 1859. Tradução Martin N. Dreher. São Leopoldo: Editora da Unisinos; Porto Alegre: PUCRS, 2003. TERNES, Apolinário. História de Joinville: uma abordagem crítica. Joinville: Meyer, 1981. VOIGT, André Fabiano. Cartas reveladas: a troca de correspondências entre Hermann Blumenau e Johann Jacob Sturz. Blumenau: Cultura em Movimento, 2004.

WALKER, Mack. Germany and the emigration, 1816-1885. Cambridge, Massachusetts: Harvard University Press, 1964.

WULFF, Henry. Norddeutsche Bank in Hamburg, 1856-1906. Berlin: Ecksteins, 1906. 